Brazilian Journal

of Chemical

Engineering

\title{
VALORIZATION OF Solanum viarum DUNAL BY EXTRACTING BIOACTIVE COMPOUNDS FROM ROOTS AND FRUITS USING ULTRASOUND AND SUPERCRITICAL $\mathrm{CO}_{2}$
}

\author{
Tássia Carla Confortinn ${ }^{1,3}$, Izelmar Todero ${ }^{1}$, Luciana Luft ${ }^{2}$, Angelico Loreto Teixeira ${ }^{3}$, \\ Marcio Antonio Mazutti ${ }^{1,2}$, Giovani Leone Zabot ${ }^{3}$ and Marcus Vinícius Tres ${ }^{3 *}$ \\ ${ }^{1}$ Universidade Federal de Santa Maria, Departamento de Engenharia Agrícola, Santa Maria, RS, Brasil. ORCID: 0000-0001-9755-5202; \\ ORCID: 0000-0003-1441-4055; ORCID: 0000-0001-8217-5629 \\ ${ }^{2}$ Universidade Federal de Santa Maria, Departamento de Engenharia Química, Santa Maria, RS, Brasil. ORCID: 0000-0001-6508-2500 \\ ${ }^{3}$ Universidade Federal de Santa Maria, Laboratório de Engenharia de Processos Agroindustriais, Cachoeira do Sul, RS, Brasil. \\ ORCID: 0000-0001-5430-2504; ORCID: 0000-0001-7933-6161; E-mail: marcus.tres@ufsm.br - ORCID: 0000-0001-5252-0735
}

(Submitted: May 30, 2019 ; Revised: September 1, 2019 ; Accepted: September 2, 2019)

\begin{abstract}
Solanum viarum Dunal belongs to the Solanaceae family and it is considered to be a grazing weed toxic to cattle. In this study, ultrasound-assisted extraction (UAE) and supercritical $\mathrm{CO}_{2}$ extraction $\left(\mathrm{SFE}-\mathrm{CO}_{2}\right)$ were applied to evaluate the extraction yield and chemical composition of fruits and roots matrices of Solanum viarum Dunal. A hydroalcoholic solution ( $60 \%$ ethanol $/ 40 \%$ water, v/v) was the solvent used for UAE. For comparisons, extractions with Soxhlet and maceration were carried out. For SFE-CO, the highest yield was obtained at $60^{\circ} \mathrm{C}$ and 250 bar. For UAE, the highest yield was obtained at an ultrasound intensity of $75.11 \mathrm{~W} / \mathrm{cm}^{2}$ and pulse cycle of 0.93 . The techniques seem to be efficient for the extraction of chemical compounds, indicating a large number of bioactive compounds. The major compounds are 1,2-benzenedicarboxylic acid, quinic acid, octadecenoic acid, and solasodine. The results highlight the application of UAE to recover compounds from vegetal matrices, since it presented higher yields and more chemical constituents when compared with other techniques.

Keywords: Solanum viarum Dunal; Ultrasound-assisted extraction; Supercritical fluids; Soxhlet; Chemical composition.
\end{abstract}

\section{INTRODUCTION}

Solanum viarum Dunal belongs to the Solanaceae family and is a native plant in South America, known as "juá" or "joá-bravo" in Brazil (Braguini et al., 2018). It is described as a broad leaf herb, subshrub or shrub (Kausar and Singh, 2018). Furthermore, it is considered to be grazing weed and highly toxic plant because it can be lethal when ingested by cattle or other herds (Mentz et al., 1997; Milner et al., 2011).

Studies about the toxicity of $S$. viarum leaves are described (Braguini et al., 2018) and report interesting chemical constituents such as solasodine, caffeoylquinic acid derivatives, 5-caffeoyl, and 3-malonyl-5-caffeoyl-[4-(1-beta-[6-(5-caffeoyl) quinate] glucopyranosyl)] and quinic acid (Kausar and Singh, 2018). The fruits belonging to the Solanaceae family can accumulate high levels of alkaloids (Cipollini and Levey, 1997), which makes the study interesting since alkaloid compounds can be highly toxic to vertebrates (Braguini et al., 2018). However, reports about techniques, extraction yield, and chemical characterization of fruits and roots of $S$. viarum have not been found in the scientific literature up to date, which makes this study extremely important.

\footnotetext{
* Corresponding author: Marcus Vinícius Tres - E-mail: marcus.tres@ufsm.br
} 
The production of secondary metabolites by plants for defense is quite common in the plant kingdom, and may be present in agricultural crops and invasive weeds (Günthardt et al., 2018). Recently, there has been a significant increase in the use of active substances found in plant extracts due to their applications in the pharmaceutical, food and agricultural sectors (De Melo et al., 2014; Kulkarni and Rathod, 2014; Zabot et al., 2016). However, some plant matrices represent potentially new applications whose knowledge, in most cases, has been empirically established or still lacks scientific coverage (De Melo et al., 2014). New techniques have been developed due to the increasing interest in bioactive compounds and in "green extraction" techniques, which overcome the problem of time and use of organic solvents (Easmin et al., 2014; Prakash Maran et al., 2017; Rouhani, 2019). Ultrasound-assisted extraction (UAE) (Wei et al. 2019) and supercritical fluid extraction (SFE) (Bubalo et al., 2015; Wei et al., 2019) are some examples of such technologies.

The type of extraction to be used plays an important role in bioactive compound extraction (Goltz et al. 2018), and UAE and SFE are being increasingly used (Kadam et al., 2013). SFE allows solvent-free extracts and, for this reason, it can be considered a green technology (Aladić et al., 2015; Moraes et al., 2015). It is also advantageous because the physicochemical properties can be adjusted by modifying the pressure and temperature conditions within the system, increasing the selectivity of extraction (Santos-Zea et al., 2019). The most commonly used solvent for extractions of bioactive compounds from natural matrices is carbon dioxide $\left(\mathrm{CO}_{2}\right)$ (Soares et al., 2018) which has advantages such as the use of mild critical temperature and pressure $\left(31^{\circ} \mathrm{C}\right.$ and $\left.74 \mathrm{bar}\right)$, and is non-toxic, non-flammable and non-polluting solvent (Gadkari et al., 2018).

$\mathrm{UAE}$ is also considered one of the main technologies to reach the target of sustainable "green" chemistry (Chemat et al., 2017). It has the advantage of decreasing extraction time and the amount of solvents (Chemat et al., 2017; Vinatoru et al., 2017; Kiss et al., 2018), as well as increasing the recovery of bioactive compounds from plants (Corbin et al., 2015). Based on this context, the objective of this work was to evaluate the UAE and SFE-CO technologies on obtaining extracts from fruits and roots of $S$. viarum. The extract yield and chemical composition were determined.

\section{MATERIALS AND METHODS}

\section{Plant material collection and preparation}

Roots and fruits of Solanum viarum Dunal were collected from a pasture area with compacted soil located at Getúlio Vargas, Rio Grande do Sul, Brazil
(S: $27^{\circ} 55^{\prime} 39.43 / \mathrm{W}: 52^{\circ} 7^{\prime} 37.14$ ). The samples were dried at $40^{\circ} \mathrm{C}$ until reaching a moisture content of approximately $10 \%$. Thereafter, the samples were milled (Marconi, SP, Brazil) and the particles were classified by the Mean Sauter Diameter using the Tyler series. The sizes ranging from 8 mesh to 48 mesh (0.3$2 \mathrm{~mm}$ ) were used for subsequent steps. The samples were maintained at $-4^{\circ} \mathrm{C}$ until the extractions.

\section{Soxhlet extraction}

Soxhlet extraction was performed using $1 \mathrm{~g}$ of vegetable matrix and $150 \mathrm{~mL}$ of $\mathrm{n}$-hexane for $150 \mathrm{~min}$ in a Soxhlet apparatus (Marconi, Model MA491/6, Brazil). The extracted mass was quantified by the gravimetric method. The assays were performed in triplicate and the responses were expressed as a mean \pm standard deviation. The Soxhlet extractions were used as a reference for comparing the yields and compositions obtained by SFE- $\mathrm{CO}_{2}$.

\section{Supercritical $\mathrm{CO}_{2}$ extraction (SFE-CO $)$}

The experimental assays of $\mathrm{SFE}-\mathrm{CO}_{2}$ were performed on a laboratory scale equipment, using carbon dioxide $\left(\mathrm{CO}_{2}\right)$ as the solvent. Details of the apparatus and procedure have been described by Confortin et al. (2019). For the extractions, approximately $10 \mathrm{~g}$ of samples (dried and milled) were used for each matrix and the $\mathrm{CO}_{2}$ flow rate was $4 \mathrm{~g} / \mathrm{min}$. During the kinetic extraction curves, the extracts were collected at equal intervals of $15 \mathrm{~min}$. The curves were constructed for all matrices under different experimental conditions in order to determine the extraction yields as a function of time using Equation (1).

$$
\operatorname{Yield}(\text { wt. } \%)=\frac{\text { Mass of extract }(\mathrm{g})}{\text { Initial dry mass of the matrix }(\mathrm{g})} \times 100
$$

The extractions were performed at temperatures of 40,50 and $60^{\circ} \mathrm{C}$ and at pressures of 150,200 and 250 bar. The fluid density $(\rho)$ was obtained from the Chemistry WebBook - Nacional Institute of Standards and Technology (NIST). The Tukey test was applied to determine the significant differences among the yields at the 5\% uncertainty level using STATISTICA $8.0{ }^{\circledR}$ (Statsoft Inc., USA).

\section{Ultrasound-assisted extraction}

Data about experimental apparatus have been described by Sallet et al. (2019). A hydroalcoholic solution $(60 \mathrm{~mL}$ of ethanol HPLC and $40 \mathrm{~mL}$ of distilled water) was used for the extractions based on previous work (Dal Prá et al., 2015). The ultrasonic probe was placed at the center of the bioreactor containing 2.5 $\mathrm{g}$ of matrix and $100 \mathrm{~mL}$ of hydroalcoholic solution. Subsequently, the temperature was adjusted to $40^{\circ} \mathrm{C}$ $\pm 2^{\circ} \mathrm{C}$ by circulating water through a jacket. After the 
extraction, the samples were centrifuged at 10,000 rpm for $5 \mathrm{~min}$, with relative centrifugal force of 5320 $\times$ g. The supernatant was carefully collected and the solvents were evaporated at $40^{\circ} \mathrm{C}$ under vacuum. The effects of ultrasound intensity $\left(17-85 \mathrm{~W} / \mathrm{cm}^{2}\right)$ and pulse cycle (0.5-1.0) on matrix extraction yields were evaluated through a central composite rotational design (CCRD). A conventional maceration without the use of the ultrasonic probe was performed as a control using the same conditions of time, temperature, and volumetric ratio.

\section{Scanning electron microscopy}

The morphology of the samples was evaluated using a scanning electron microscope (SEM) (Tescan, VEGA3G, Czech Republic) coupled to a secondary electron detector to obtain the images. For this analysis, the samples were covered with $\mathrm{Au}$ (sputtering metallization process, using a current of $20 \mathrm{~mA}$ for $90 \mathrm{~s}$ ).

\section{Chemical characterization of extracts by gas chromatography}

The samples obtained by SFE- $\mathrm{CO}_{2}$ were analyzed in a GC-Q/MS system (Shimadzu, Japan). The autosampler was an AOC-20is series injector, the gas chromatograph was a GC-2010 Plus and the mass spectrometer was a GCMS-QP2010 Ultra. The column was a $30 \mathrm{~m} \times 0.25 \mathrm{~mm}$ i.d. fused silica capillary column coated with $0.25 \mu \mathrm{m}$ Rtx-5MS (Restek). Helium was the carrier gas at a flow rate of $1.69 \mathrm{~mL} /$ min. The injector temperature was maintained at $270^{\circ} \mathrm{C}$. A volume of $1 \mu \mathrm{L}$ of each sample was injected at a 1:10 split ratio. The oven temperature program used was $5^{\circ} \mathrm{C} / \mathrm{min}$ from $50^{\circ} \mathrm{C}$ to $280^{\circ} \mathrm{C}$ (hold $15 \mathrm{~min}$ ). The interface temperature was held at $280^{\circ} \mathrm{C}$ and the ion source temperature at $280^{\circ} \mathrm{C}$. Mass spectra were recorded over the 35-500 amu range at $3.33 \mathrm{scan} / \mathrm{s}$, with ionization energy of $70 \mathrm{eV}$. The identification of individual components was done using their relative retention indices with the Wiley Registry of Mass Spectral Data (Palisade Corporation, Newfield, USA).

For the UAE, the same method of analysis was used with some modifications. The flow rate was $1.18 \mathrm{~mL} /$ min and the injector temperature were maintained at $320^{\circ} \mathrm{C}$. A volume of $1 \mu \mathrm{L}$ of each sample was injected at a 1:40 split ratio. The oven temperature program used was $5^{\circ} \mathrm{C} / \mathrm{min}$ from $80^{\circ} \mathrm{C}$ to $300^{\circ} \mathrm{C}$ (hold $14 \mathrm{~min}$ ). The interface temperature was held at $320^{\circ} \mathrm{C}$ and the ion source temperature was held at $260^{\circ} \mathrm{C}$.

\section{RESULTS AND DISCUSSION}

\section{Yields of extracts from SFE-CO,}

The extraction yields obtained by Soxhlet and SFE- $\mathrm{CO}_{2}$ from fruits and roots of Solanum viarum are shown in Table 1 . The highest yields were obtained
Table 1. Comparison of extraction yields obtained from Solanum viarum using SFE- $\mathrm{CO}_{2}$ and Soxhlet.

\begin{tabular}{|c|c|c|c|c|c|}
\hline \multirow{2}{*}{ Assay } & \multirow{2}{*}{$\begin{array}{c}\mathrm{T} \\
\left({ }^{\circ} \mathrm{C}\right)\end{array}$} & \multirow{2}{*}{$\begin{array}{c}\mathbf{P} \\
\text { (bar) }\end{array}$} & \multirow{2}{*}{$\begin{array}{c}\mathbf{P} \\
\left(\mathrm{kg} / \mathrm{m}^{3}\right)\end{array}$} & \multicolumn{2}{|c|}{ Yield (wt.\%) } \\
\hline & & & & Fruits & Roots \\
\hline & & & SFE-C & & \\
\hline 1 & $(-1) 40$ & $(+1) 150$ & 750.501 & $\pm 0.002^{\mathrm{cD}}$ & $0.17 \pm 0.001^{\mathrm{cD}}$ \\
\hline 2 & $(-1) 40$ & $(+1) 250$ & 887.534 & $69 \pm 0.001^{\mathrm{aB}}$ & $0.37 \pm 0.001^{\mathrm{aB}}$ \\
\hline 3 & $(+1) 60$ & $(-1) 150$ & 565.509 & $40 \pm 0.002^{\mathrm{dE}}$ & $0.12 \pm 0.001^{\mathrm{dE}}$ \\
\hline 4 & $(+1) 60$ & $(+1) 250$ & 776.880 & $63 \pm 0.002^{\mathrm{bC}}$ & $0.24 \pm 0.001^{\mathrm{bC}}$ \\
\hline 5 & (0) 50 & (0) 200 & 765.942 & $.44 \pm 0.002^{\mathrm{eF}}$ & $0.14 \pm 0.003^{\mathrm{eF}}$ \\
\hline 6 & (0) 50 & (0) 200 & 765.942 & $43 \pm 0.002^{\mathrm{eF}}$ & $0.13 \pm 0.003^{\mathrm{eF}}$ \\
\hline 7 & (0) 50 & (0) 200 & 765.942 & $44 \pm 0.002^{\mathrm{eF}}$ & $0.14 \pm 0.003^{\mathrm{eF}}$ \\
\hline
\end{tabular}

(-1): inferior coded level; (+1): superior coded level.

$\mathrm{T}$ : temperature; P: pressure; $\rho$ : density; Nd: not determined.

a-e Different letters in the same column represent a significant difference at $95 \%(\mathrm{p}<$ 0.05 - Tukey test) among the assays for each solvent.

A-F Different letters in the same column represent a significant difference at $95 \%$ (p $<0.05$ - Tukey test) among the assays between both solvents.

using Soxhlet extraction for the fruits (1.87 wt.\%) and roots $(0.52 \mathrm{wt.} \%)$. Both matrices showed similar behavior in relation to yields by SFE- $\mathrm{CO}_{2}$, where the highest yields $(0.69 \pm 0.001 \mathrm{wt} . \%$ fruits and $0.37 \pm 0.001$ wt.\% roots) were obtained in the lowest temperature and the highest pressure $\left(40^{\circ} \mathrm{C} / 250\right.$ bar $)$ assay, while the lowest yields $(0.40 \pm 0.002$ wt.\% fruits and $0.12 \pm 0.001 \mathrm{wt} . \%$ roots) were obtained in the assay of higher temperature and lower pressure $\left(60^{\circ} \mathrm{C} / 150 \mathrm{bar}\right)$.

The increase of pressure from 150 to 250 bar resulted in a higher yield of extract. Otherwise, the increase in temperature from 40 to $60^{\circ} \mathrm{C}$ caused a lower yield. This effect is due to solvent density because the increase of pressure increases the density of the supercritical fluid. Consequently, the solvating power of the solvent is increased. An increase in temperature causes a density decrease and, consequently, a decrease of solubility of extracts in $\mathrm{CO}_{2}$ (Soares et al., 2016; Goyeneche et al., 2018). Goyeneche et al. (2018) reported the same behavior of this study when studying radish leaves. The increase of pressure favored the yield while the increase of temperature hampered the yield. This effect was also identified in the works of Alvarez et al (2019) and Elgndi et al. (2017).

An important aspect to be considered when studying extraction processes are the general extraction curves (Dal Prá et al., 2016). The extraction curves are useful for improving the processes and calculating the manufacturing costs (Martinez-Correa et al., 2017). One of the difficulties of using supercritical technology is the high initial cost of investment (Goyeneche et al., 2018), which could be overcome by optimizing process parameters (Zabot et al., 2018). However, despite the high initial cost, some studies have demonstrated the economic feasibility of SFE$\mathrm{CO}_{2}$ (Farías-Campomanes et al., 2013, Prado et al., 2012, Zabot et al., 2015).

The extraction curves obtained in this work (Figure 1) are divided into three stages. The first is the constant 
rate period controlled by the convective mass transfer mechanism. Posteriorly, the other period is known as diffusion and convection, where extraction occurs. The third period, where the extraction rate is low, is mainly controlled by diffusion (Alvarez et al., 2019). As can be seen in Figure 1, there was a high extraction rate at the beginning of the process and there was a rapid reduction in the extraction rate in the subsequent minutes. According to Martinez-Correa et al. (2017), this behavior indicates that the process is controlled by diffusion.

The constant extraction rate was verified for fruits in the first $60 \mathrm{~min}$, while for the roots it was in the first 15 min. In these periods, most of the solutes are removed from this matrix, predominating the convective mass transfer (Valente et al., 2018). For fruits, fractions of $75.5 \%, 66.7 \%, 73.8 \%, 93.6 \%$ and $93.6 \%$ (mass basis) of the total mass of extract available in such matrix were recovered in assays 1-5, respectively. For roots, fractions of $66.7 \%, 91.5 \%, 84.6 \%, 86.9 \%$ and $80.0 \%$ (mass basis) of the total mass of extract available in such matrix were recovered in assays $1-5$, respectively.
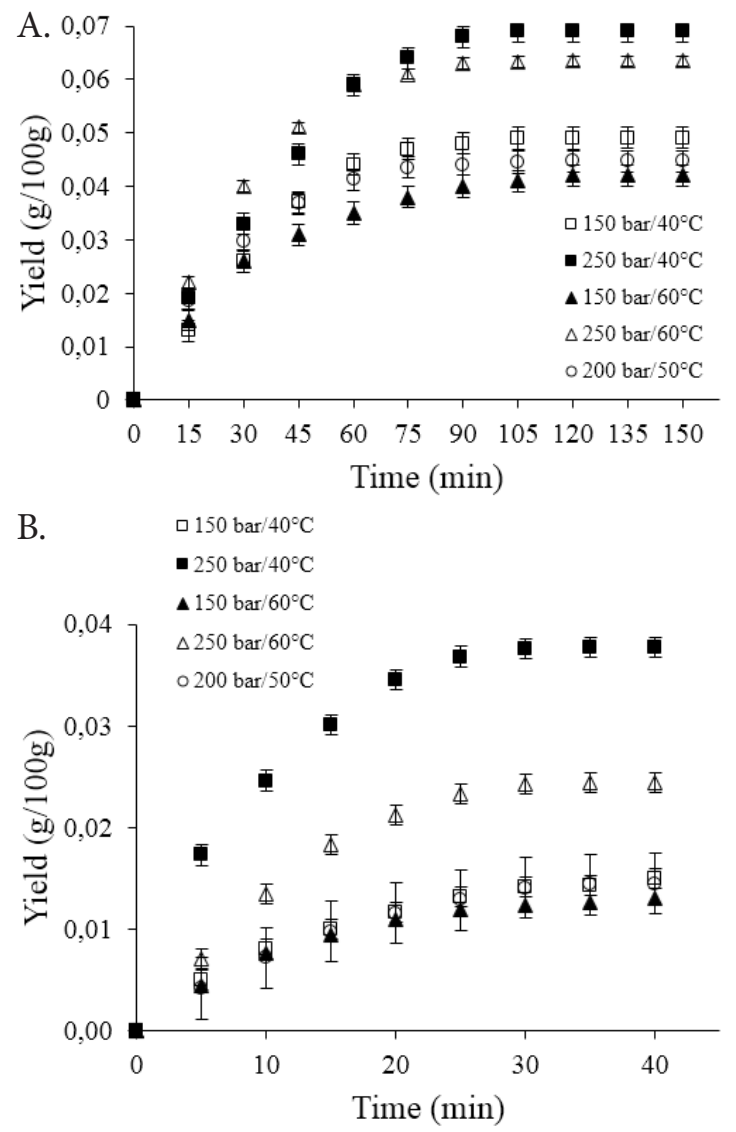

Figure 1. Kinetic curves for extraction of bioactive compounds from Solanum viarum using SFE- $\mathrm{CO}_{2}$ for (a) fruits and (b) roots matrices.

\section{Ultrasound-assisted extraction}

Table 2 shows the extraction yields obtained in the eleven assays of CCRD, ranging from $10.5 \mathrm{wt} . \%$
Table 2. Yields obtained from fruits and roots from Solanum viarum using UAE.

\begin{tabular}{ccccc}
\hline \multirow{2}{*}{ Assay } & $\begin{array}{c}\text { Ultrasound } \\
\text { intensity (W/cm }\end{array}$ & Pulse & \multicolumn{2}{c}{ Yield (wt.\%) } \\
\cline { 4 - 5 } & cycle (-) & Fruits & Roots \\
\hline 1 & $26.89(-1)$ & $0.57(-1)$ & 10.5 & 1.3 \\
2 & $75.11(1)$ & $0.57(-1)$ & 18.6 & 8.7 \\
3 & $26.89(-1)$ & $0.93(1)$ & 16.6 & 6.4 \\
4 & $75.11(1)$ & $0.93(1)$ & 20.8 & 11.7 \\
5 & $17(-1.41)$ & $0.75(0)$ & 12.0 & 2.9 \\
6 & $85(1.41)$ & $0.75(0)$ & 19.5 & 10.2 \\
7 & $51(0)$ & $0.50(-1.41)$ & 16.9 & 6.9 \\
8 & $51(0)$ & $1.0(1.41)$ & 18.2 & 8.2 \\
9 & $51(0)$ & $0.75(0)$ & 17.1 & 7.1 \\
10 & $51(0)$ & $0.75(0)$ & 17.9 & 7.2 \\
11 & $51(0)$ & $0.75(0)$ & 17.8 & 7.5 \\
$12^{\text {a }}$ & 0 & 0 & 9.7 & 1.1 \\
\hline a - Maceration - control (Extraction without ultrasound).
\end{tabular}

to 20.8 wt.\% for fruits and from 1.3 wt. $\%$ to $11.7 \%$ wt. $\%$ for roots. The two matrices demonstrated very similar behaviors, having the highest yields in assay 4 with high intensity $\left(75.11 \mathrm{~W} / \mathrm{cm}^{2}\right)$ and a pulse cycle of 0.93 . The lowest yield was obtained in assay 1 with the lowest intensity and pulse cycle.

Comparing the assays 4 (highest yield) and 12 (maceration control), the yields increased approximately 2 and 10 times for fruits and roots, respectively. These data are corroborated by Rouhani (2019), who obtained a higher yield $(79 \%)$ in stevioside extraction from Stevia rebaudiana using UAE, when compared to the control (22\%). According to Sallet et al. (2019), whose findings also corroborate the results of the current work, the main reason for this behavior is the increase of mass transfer in the system when ultrasound is employed. In the current study, the effect of cavitation and its subsequent effects allowed a breakdown of the cell walls of the plant matrix, improving the penetration of solvent and facilitating the release of extractable compounds, consequently increasing the yields, as reported elsewhere (Picó, 2013; Bernardo et al., 2018).

The data presented in Table 2 were used to calculate the linear, quadratic and interaction terms of the process variables in the response, which were expressed as a Pareto chart in Figure 2. The linear terms for the pulse cycle and ultrasound intensity were statistically significant $(p<0.05)$ for both matrices. The intensity of ultrasound showed a positive effect, whose increase may lead to higher yields for both matrices. When comparing assays 1-2 and 3-4, the highest yields were obtained at the highest ultrasound intensity $\left(75.11 \mathrm{~W} / \mathrm{cm}^{2}\right)$, when the pulse cycle is maintained constant at levels -1 and + 1, respectively. According to Chemat et al. (2017), the ultrasound intensity is a relevant parameter that strongly affects the efficiency of extraction because its increase causes a strong bubble collapse, breaking the plant structures. 

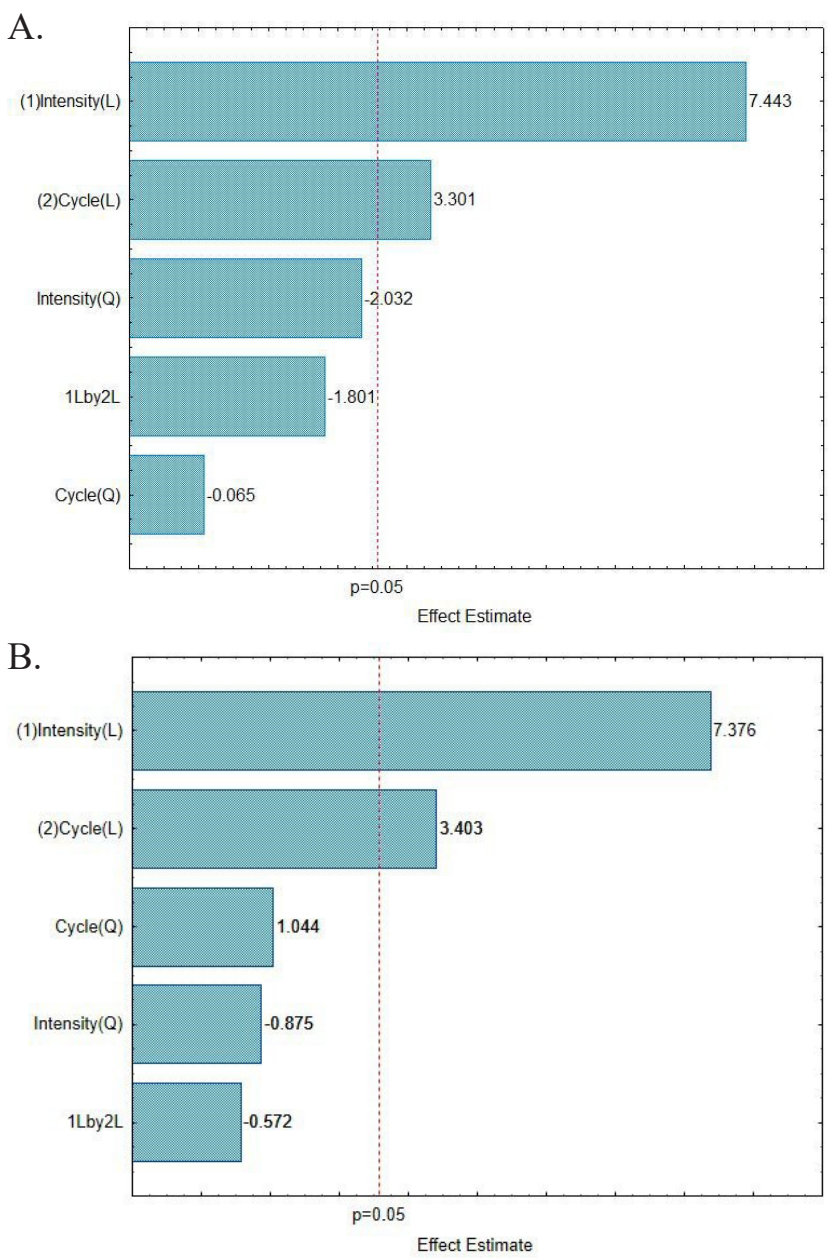

Figure 2. Pareto chart expressing the effect of process variables on the extraction yield using UAE for (a) fruits and (b) roots matrices.

The quadratic term for ultrasound intensity showed a negative effect on matrix yields. The negative signals of the quadratic term indicate the presence of a maximum point for the ultrasound intensity in the evaluated range, showing that it would be interesting to optimize the ultrasound intensity before extractions on a larger scale (Kulkarni and Rathod, 2014), since it can reduce the energy costs (Sallet et al., 2019).

In order to show the influence of ultrasound intensity and pulse cycle on the extraction yield, contour plots were generated (Figure 3). UAE of extracts from fruits of Solanum viarum yielded the maximum extraction yield for ultrasound intensity ranging from $55 \mathrm{~W} /$ $\mathrm{cm}^{2}$ to $85 \mathrm{~W} / \mathrm{cm}^{2}$, and pulse cycle ranging from 0.5 to 1 . For the roots, the maximum extraction yield was obtained for ultrasound intensity ranging from $60 \mathrm{~W} /$ $\mathrm{cm}^{2}$ to $85 \mathrm{~W} / \mathrm{cm}^{2}$ and pulse cycle ranging from 0.75 to 1. The increase of intensity and pulse cycle favors the recovery of extracts from the matrices studied in this work.

The UAE technique also presented yields superior to SFE- $\mathrm{CO}_{2}$ and Soxhlet techniques, and in a shorter
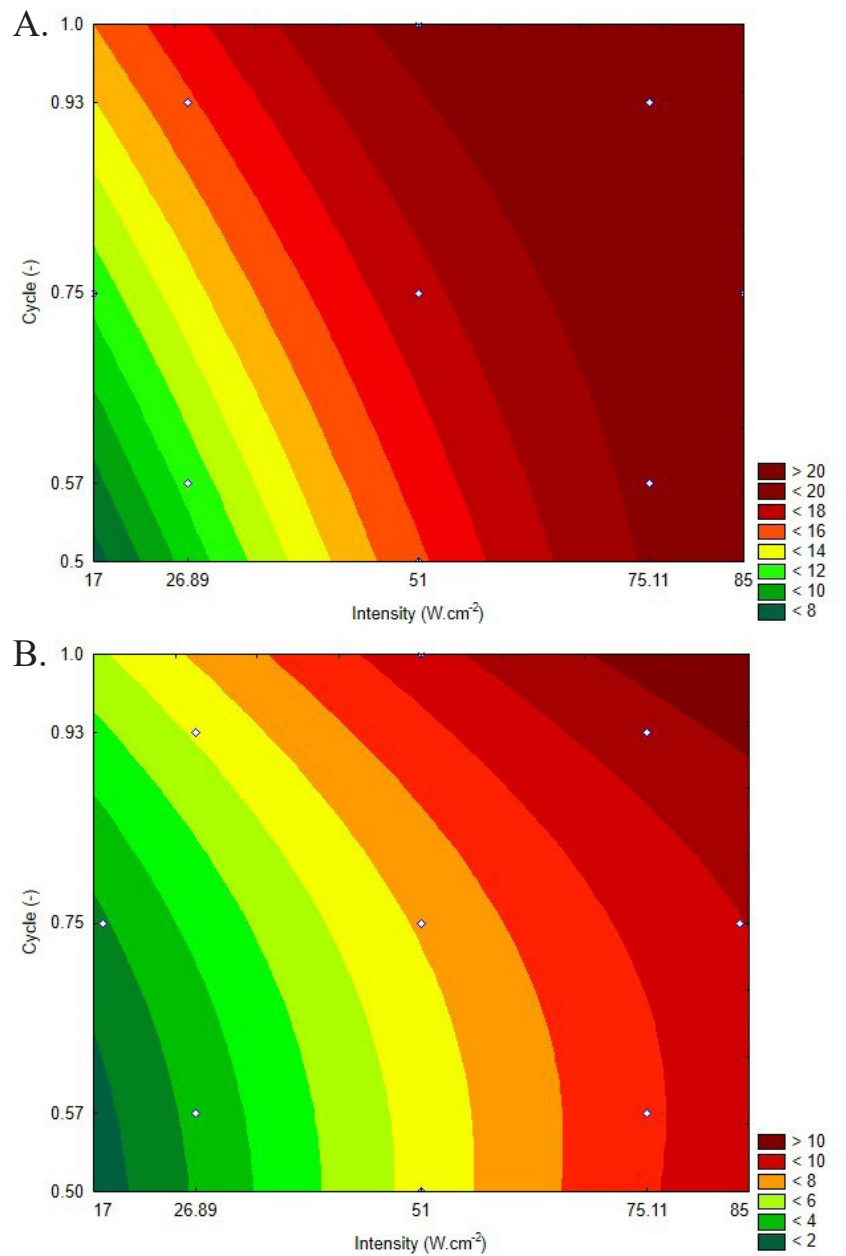

Figure 3. Contour plots expressing the influence of process variables on the extraction yield using UAE for the fruits (a) and roots (b) matrices.

time. The UAE increased the efficiency of canola oil extraction compared to the Soxhlet method (Jalili et al., 2018). Positive effects of UAE for obtaining euphol from Euphorbia tirucalli (Vuong et al., 2015) and Moringa peregrina oil (Mohammadpour et al., 2019) were also reported. According to Mohammadpour et al. (2019), the application of ultrasound has become a recent and promising method in oil extraction from plants.

To better understand the efficiency of the different techniques and the structural changes that occurred before and after extractions, the surface of the particles of $S$. viarum matrices was evaluated by SEM. For fruits, the seeds were analyzed separately. The surface of matrix tissues showed integrity before extraction, but was slightly damaged after extractions. With the application of all of the techniques, there were changes in the tissue surface (Figures 4 and 5).

$\mathrm{SFE}-\mathrm{CO}_{2}$ showed damage to cells in the form of cracking and scaling, much higher than when the Soxhlet was applied. In maceration, a crushing occurred, while cavitation breaks the entire surface of 

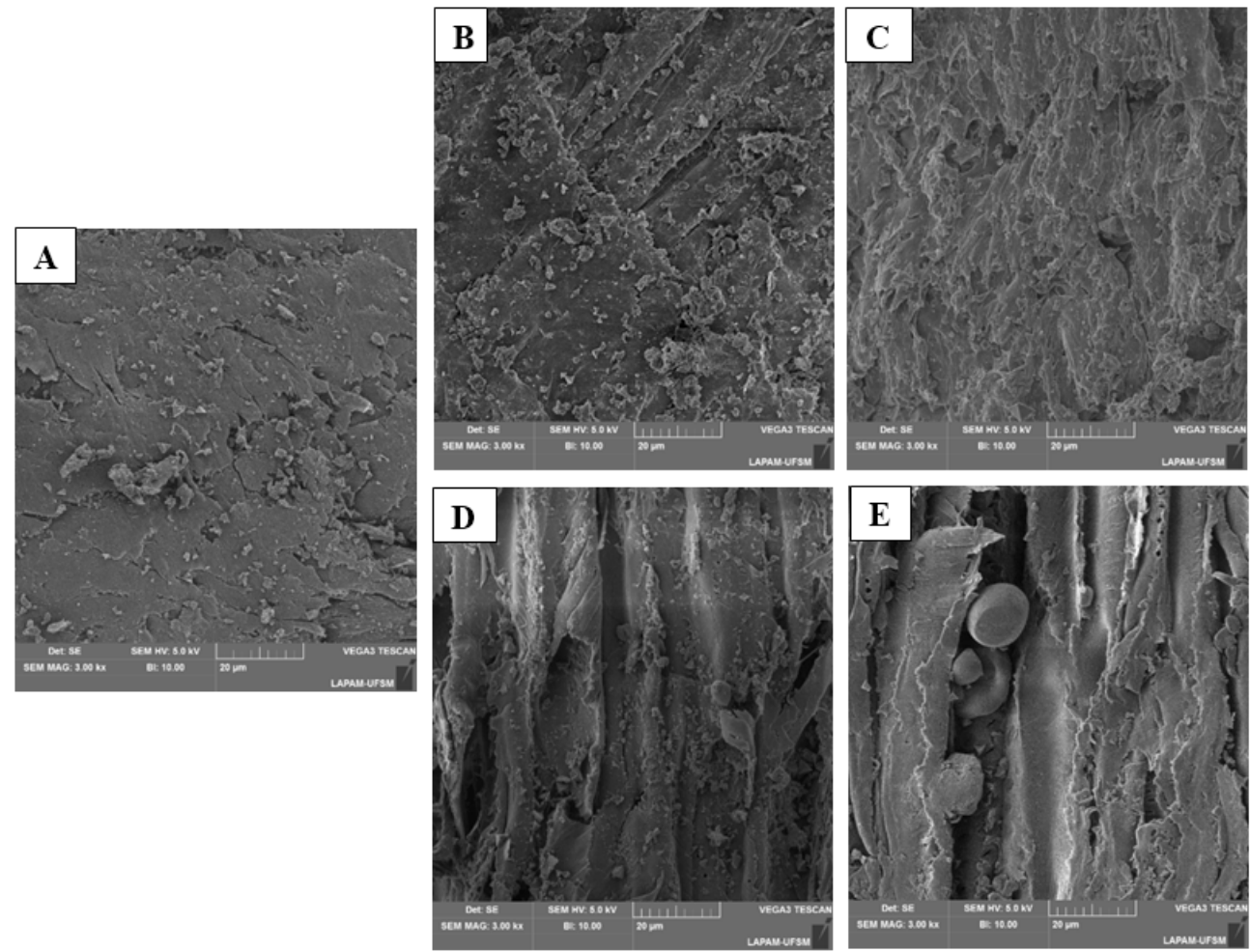

Figure 4. SEM images of roots before and after extraction: (A) fresh (before extractions); (B) Soxhlet extraction; (C) SFE-CO ${ }_{2}$ (D) maceration; and (E) UAE.
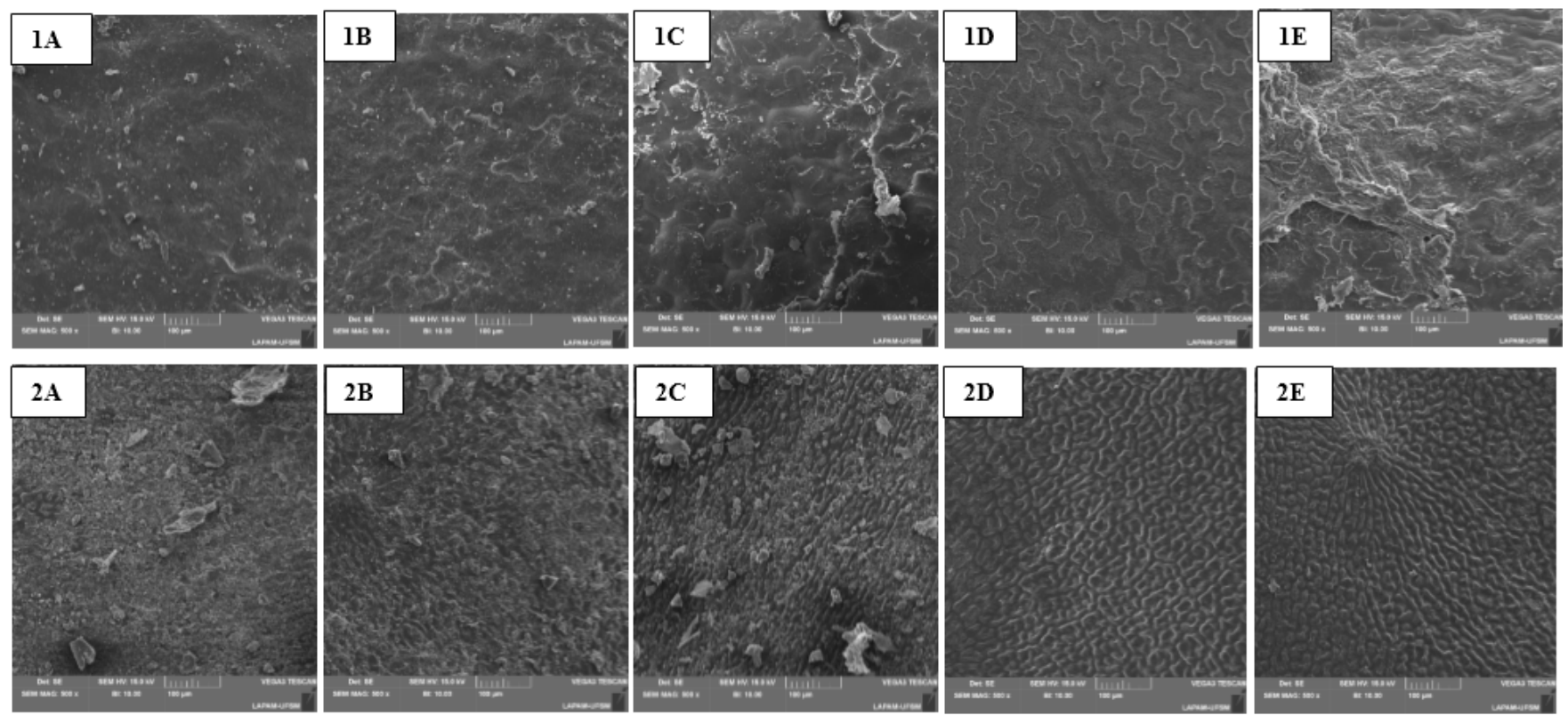

Figure 5. SEM images of fruits before and after extraction: (A) in nature; (B) Soxhlet extraction; (C) SFE- $\mathrm{CO}_{2}$; (D) maceration; (E) UAE; (1) seeds and (2) husks.

leaves. The UAE process showed more visible changes such as openings in the cellular structures that could be correlated with explosive rupture. This could be evidence of the occurrence of cavitation phenomena, which facilitate the general extraction process (Patil and Akamanchi, 2017). The images revealed that more cracks and pores were created by ultrasound, favoring the extraction more rapidly.
The implosion of cavitation bubbles on the surface of matrices induces the erosion of released structures in the extraction medium. Some authors have reported the erosion of plant material when it was treated by ultrasound. For example, UAE of boldo leaf was studied by Petigny et al. (2013) using an ultrasound probe. Mohammadpour et al. (2019) also described structural changes in Moringa peregrina using different 
extraction techniques (UAE and Soxhlet). Zhou et al. (2018) also observed damage in mulberry leaves using the UAE technique, indicating this method as convenient and versatile for the effective extraction of bioactive phytochemical products. Zhong et al. (2018) suggest that ultrasound is the most effective way to destroy the cellular structure of seed samples and favor the release of the solvent extraction oil used.

\section{Chemical composition}

The extracts obtained from fruits and roots of Solanum viarum contain phytochemical constituents. Most of them are known to be biologically active compounds and are responsible for displaying various activities. Twenty compounds were identified and quantified in extracts from both matrices obtained under different conditions using SFE- $\mathrm{CO}_{2}$ (Table 3).

Almost all the identified compounds were found in the two morphological parts studied. However, the percentage is different for some of them. The major compounds for SFE- $\mathrm{CO}_{2}$ in both matrices were 1,2-benzenedicarboxylic acid, octadecanoic acid, hexadecanoic acid, and Vitamin E. These compounds were also identified and reported as to their bioactivity by various authors. For instance, Ali et al. (2017) describes 1,2-benzenedicarboxylic acid as an antifungal compound, responsible for growth control of Fusarium oxysporum and Lycopersici sp.. Verma et al. (2014) extracted 1,2-benzenedicarboxylic acid from Aspergillus flavipes and tested its antifungal efficacy against Sclerotin sclerotiorum. Govindappa et al. (2014) and Krishnan et al. (2014) reported antimicrobial, cytotoxicity, antioxidant, antiinflammatory and antiviral activities for this referenced compound.

According to Linton et al. (2013), octadecanoic acid exhibits antiviral, antioxidant and antibacterial activities, and according to Selvamangai and Bhaskar (2012), it is responsible for hypocholesterolemic, antiarthritic and nematicide actions. Sanseera et al. (2013) studied the chemical composition and biological activities of leaf essential oil of Cleidion javanicum, which presented significant antimicrobial, antioxidant and anticancer activity, wherein its composition is hexadecanoic acid (26.77\%). Selvamangai and Bhaskar (2012) and Agoramoorthy et al. (2007) attribute antiinflammatory, antioxidant and antibacterial activities to this compound.

Another aspect to be highlighted is the higher yields and the target compounds recovered in the processes. Different compounds were observed under conditions of temperature and pressure (Table 3). The condition of the highest yield was not the same as the one with the highest percentage of area in the major compounds. These findings indicate that SFE$\mathrm{CO}_{2}$ was more selective to extract the largest number of compounds in less quantity of extract. Interfering compounds or inhibitors can be extracted in larger quantities under better yield conditions, thus reducing the quality of extract (Confortin et al. 2017). When comparing the percent area of compounds, it is evident that supercritical $\mathrm{CO}_{2}$ exceeded the conventional method of Soxhlet extraction. Although the Soxhlet technique can provide higher yields, the extract has

Table 3. Chemical compounds obtained by SFE- $\mathrm{CO}_{2}$ and Soxhlet for fruits and roots matrices of Solanum viarum.

\begin{tabular}{|c|c|c|c|c|c|c|c|c|c|c|c|c|}
\hline \multirow{4}{*}{ Assay } & \multicolumn{12}{|c|}{ Relative area (\%) } \\
\hline & \multicolumn{6}{|c|}{ Fruits } & \multicolumn{6}{|c|}{ Roots } \\
\hline & \multicolumn{5}{|c|}{ SFE-CO } & \multirow{2}{*}{ Soxhlet } & \multicolumn{5}{|c|}{$\mathrm{SFE}_{\mathrm{CO}} \mathrm{O}_{2}$} & \multirow[b]{2}{*}{ Soxhlet } \\
\hline & 1 & 2 & 3 & 4 & $5 / 6 / 7$ & & 1 & 2 & 3 & 4 & $5 / 6 / 7$ & \\
\hline \multicolumn{13}{|c|}{ Compounds } \\
\hline 2-Heptenal & 1.13 & 2.56 & - & 1.66 & - & 1.04 & 1.85 & 2.5 & 2.1 & 1.2 & 1.89 & 0.89 \\
\hline 2,4-Decadienal & 3.58 & 1.66 & - & - & - & 1.52 & 2.0 & 1.86 & 2.86 & 2.56 & 2.10 & 1.52 \\
\hline Hexadecamethylcyclooctasiloxane & 1.05 & 1.01 & 0.89 & 2.61 & 2.52 & 1.68 & 1.52 & 1.58 & 1.89 & 1.92 & 1.83 & 2.0 \\
\hline 2-Hexadecen-1-ol, 3,7,11,15-tetramethyl- & 1.38 & 1.14 & 0.98 & 2.53 & 1.04 & 2.0 & 0.89 & 0.65 & 0.96 & 0.88 & 1.0 & 0.70 \\
\hline 3,7,11,15-Tetramethyl-2-hexadecen-1-ol & 0.92 & 1.12 & - & - & - & - & - & - & - & - & - & - \\
\hline Benzoic acid & 1.22 & 1.20 & 1.31 & 1.27 & 1.23 & 2.49 & 1.69 & 1.63 & 2.89 & 3.89 & 4.72 & 1.0 \\
\hline 9-Octadecenoic acid & 1.50 & 2.71 & 1.57 & 1.85 & 3.21 & 1.42 & 1.86 & 1.05 & 1.89 & 1.23 & 2.05 & 0.89 \\
\hline Hexadecanoic acid & 11.15 & 8.67 & 9.22 & 8.45 & 8.08 & 4.37 & 8.56 & 4.52 & 5.56 & 3.58 & 5.58 & 2.05 \\
\hline Nonadecane & 1.93 & 1.16 & 1.10 & 2.56 & 1.96 & 2.89 & 1.56 & 1.30 & 1.89 & 1.93 & 2.0 & 0.2 \\
\hline 9,12-Octadecanoic acid & 12.55 & 10.0 & 15.10 & 18.11 & 19.10 & 3.41 & 10.52 & 11.65 & 13.56 & 10.58 & 9.85 & 5.58 \\
\hline 1,2-Benzenedicarboxylic acid & 40.0 & 25.0 & 22.31 & 25.08 & 25.28 & 4.91 & 25.58 & 22.10 & 25.58 & 30.52 & 28.56 & 10.52 \\
\hline Octadecanal & 2.30 & 3.26 & - & 1.26 & - & 4.10 & 2.86 & 2.1 & 2.0 & 2.23 & 2.32 & 1.56 \\
\hline Neophytadiene & - & 1.09 & 1.19 & - & - & 1.56 & 2.0 & 1.5 & 1.6 & 0.76 & 0.86 & 0.86 \\
\hline Linalool & 1.90 & 1.10 & 2.45 & 1.94 & 2.20 & 1.0 & 1.01 & 1.02 & 2.02 & 2.65 & 3.58 & - \\
\hline Eicosane & - & 2.37 & 1.25 & 1.52 & 2.58 & - & 1.58 & 1.96 & 1.86 & 2.0 & 2.01 & 1.2 \\
\hline Vitamin E & 10.84 & 10.17 & 20.31 & 19.81 & 20.88 & 5.58 & 8.56 & 6.58 & 7.62 & 8.58 & 8.02 & 4.28 \\
\hline Farnesol 2 & 2.25 & 1.05 & 2.89 & 1.60 & 3.0 & 1.62 & 1.89 & 1.25 & 1.10 & 2.0 & 1.96 & - \\
\hline Octadecane & 2.52 & 2.85 & 3.96 & 3.69 & 3.85 & 1.02 & 1.50 & 1.83 & 2.76 & 3.06 & 3.89 & 0.8 \\
\hline Celidoniol & 1.0 & 2.0 & 1.30 & 2.89 & 2.35 & 0.89 & 1.56 & 0.89 & 0.96 & 0.89 & 1.10 & - \\
\hline 2,6,10,14,18-Pentamethyl & 0.82 & 1.50 & 1.12 & 1.0 & 1.72 & 0.50 & 0.96 & 1.0 & - & - & - & - \\
\hline Waxes & 1.96 & 18.38 & 13.05 & 2.17 & 1.0 & 60 & 22.05 & 33.03 & 20.90 & 19.54 & 16.68 & 65.95 \\
\hline
\end{tabular}


higher amounts of waxes, influencing the identification of bioactive compounds.

The 46 compounds identified using UAE (Table 4) were higher than those obtained by SFE-CO (non-polar solvent). The results found in this work can be explained by higher solubility of extracts in hydroalcoholic solution, as compared to $\mathrm{CO}_{2}$. As $\mathrm{CO}_{2}$ is non-polar, the solubility of highly polar compounds is low (Cabaleero, 2018; Alvarez et al., 2019). There are some reports confirming that the ultrasoundassisted method results in increased extraction yield of various phytochemicals at reduced extraction time and lower solvent consumption (Jalili et al., 2018; Zhong et al., 2018).

The highest number of compounds was obtained at $85 \mathrm{~W} / \mathrm{cm}^{2}$ of ultrasound intensity and 0.75 of pulse

Table 4. Chemical compounds obtained by UAE for fruits and roots matrices of Solanum viarum.

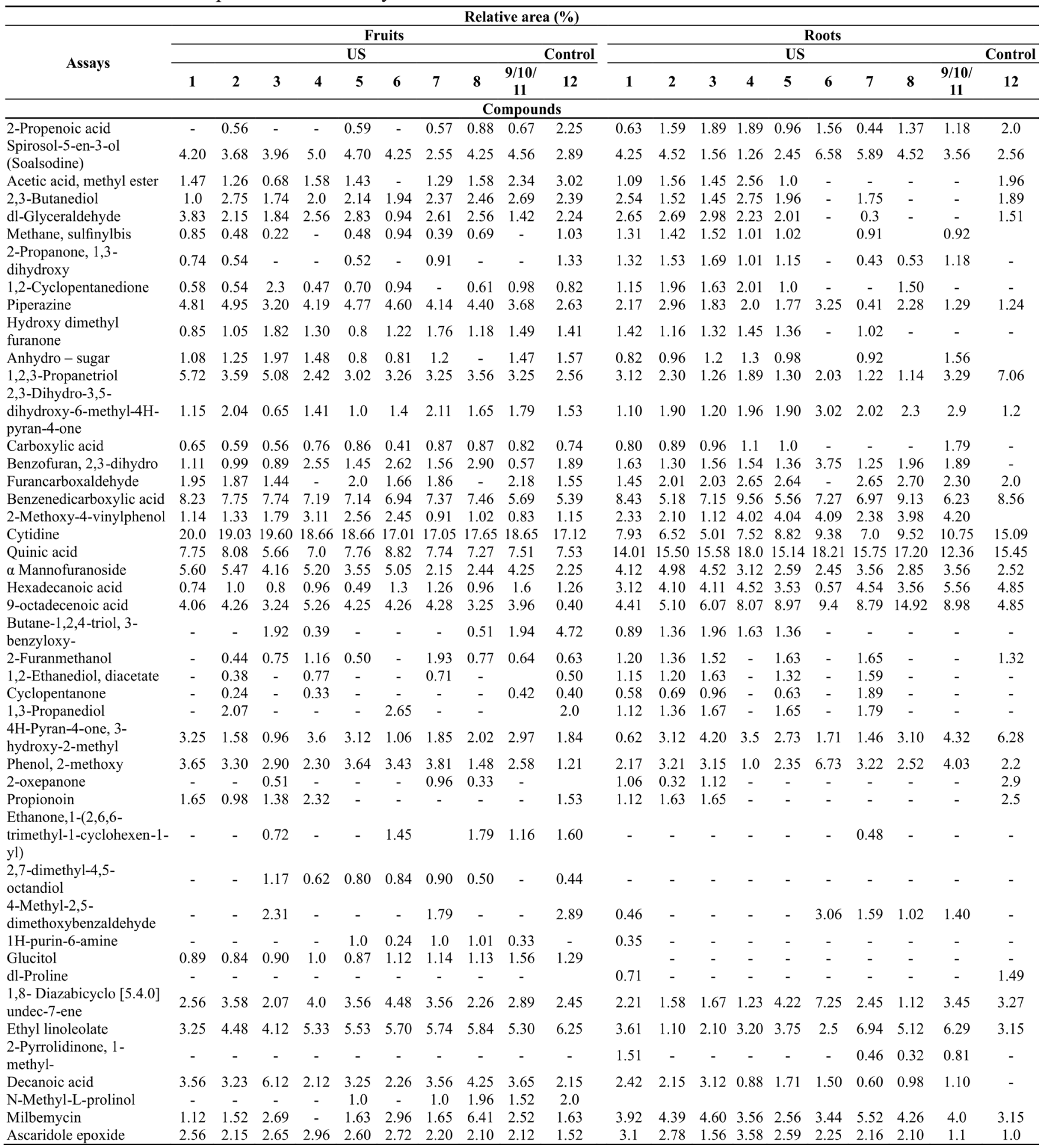


cycle, showing that high ultrasound intensities lead to extraction of more quantity of bioactive compounds. As previously mentioned, the positive effect of increased power on yield can be explained by violent collapses of cavitation bubbles, causing further destruction of the cell walls of the raw material and, therefore, facilitating the access of solvent to the analytes (Goltz et al., 2018; Santos et al., 2019).

The major compounds were the same for both matrices:quinicacid, cytidine, 1,2-benzenedicarboxylic

Table 5. Activities reported in the literature of some compounds found in this work.

\begin{tabular}{|c|c|c|}
\hline Compound & Bioactivity & Reference \\
\hline Farnesol & $\begin{array}{c}\text { Cytotoxic } \\
\text { Used in dermatological formulations } \\
\text { Antifungal }\end{array}$ & $\begin{array}{l}\text { Santos et al. (2019) } \\
\text { Piochon al. (2009) } \\
\text { Pauli (2006) }\end{array}$ \\
\hline 2-heptenal & Aromatic compound & $\begin{array}{l}\text { Miranda et al.(2008) } \\
\text { Chen et al.(2018) }\end{array}$ \\
\hline 2,4-decadienal & Aromatic compound & $\begin{array}{l}\text { Miranda et al.(2008) } \\
\text { Chen et al. (2018) }\end{array}$ \\
\hline Phenol & $\begin{array}{l}\text { Antimicrobial } \\
\text { Antioxidant } \\
\text { Anti-inflammatory }\end{array}$ & $\begin{array}{l}\text { Muthulakshmi et al.(2012) } \\
\text { Barretto and Vootla (2018) }\end{array}$ \\
\hline Celidoniol & $\begin{array}{c}\text { Antimicrobial } \\
\text { Anti-inflammatory }\end{array}$ & Barretto and Vootla (2018) \\
\hline Nonadecane & $\begin{array}{l}\text { Antimicrobial } \\
\text { Cytotoxic }\end{array}$ & $\begin{array}{c}\text { Barretto and Vootla (2018) } \\
\text { Hsouna et al. (2011) }\end{array}$ \\
\hline $\begin{array}{l}\text { Eicosane } \\
\text { Octadecane }\end{array}$ & $\begin{array}{l}\text { Antitumoral } \\
\text { Antifungal }\end{array}$ & $\begin{array}{l}\text { Amanian and Brindha (2013) } \\
\text { Abu backer and Devi(2015) }\end{array}$ \\
\hline Glucitol & $\begin{array}{c}\text { Surfactants } \\
\text { Emulsifying and stabilizing effects } \\
\text { Fragrance }\end{array}$ & $\begin{array}{l}\text { Marques et al. (2016) } \\
\text { Aminah et al.(2013) }\end{array}$ \\
\hline Ethyl linoleolate & $\begin{array}{l}\text { Antimicrobial } \\
\text { Antioxidant } \\
\text { Anticancer } \\
\text { Antioxidant }\end{array}$ & Sanseera et al. (2013) \\
\hline Linalool & $\begin{array}{l}\text { Anticancer } \\
\text { Antimicrobial } \\
\text { Antimicrobial }\end{array}$ & Lichtfouse (2013) \\
\hline Propanetriol & $\begin{array}{l}\text { Anti-inflammatory } \\
\text { Anticancer } \\
\text { Antifungal }\end{array}$ & $\begin{array}{l}\text { Casuga et al. (2016) } \\
\text { Foo et al. (2015) }\end{array}$ \\
\hline 2,3-Dihydro-3,5-dihydroxy-6-methyl-4H-pyran-4-one & $\begin{array}{l}\text { Antimicrobial } \\
\text { Anti-inflammatory } \\
\text { Antioxidant }\end{array}$ & Foo et al. (2015) \\
\hline Benzoic acid & $\begin{array}{l}\text { Antimicrobial } \\
\text { Antimicrobial }\end{array}$ & Foo et al. (2015) \\
\hline 2-Methoxy-4-vinylphenol & $\begin{array}{l}\text { Antioxidant } \\
\text { Anti-inflammatory } \\
\text { Analgesic }\end{array}$ & Foo et al. (2015) \\
\hline Benzofuran, 2,3-dihydro & $\begin{array}{c}\text { Antimicrobial } \\
\text { Anti-inflammatory }\end{array}$ & Foo et al. (2015) \\
\hline Phenol, 2-methoxy & Antimicrobial & Foo et al. (2015) \\
\hline Decanoic acid & $\begin{array}{l}\text { Nematicidal } \\
\text { Pesticide } \\
\text { High toxicity }\end{array}$ & Selvamangai and Bhaskar(2012) \\
\hline 2-Propenoic acid & $\begin{array}{l}\text { Insecticidal } \\
\text { Herbicidal } \\
\text { Antifungal }\end{array}$ & Fraga et al. (2017) \\
\hline Piperazine & Nematicidal & Demuner et al. (2001) \\
\hline Mannofuranoside & $\begin{array}{l}\text { Anti-bacterial } \\
\text { Antifungal }\end{array}$ & Hugar and Londonkar(2017) \\
\hline Ascaridole & $\begin{array}{l}\text { Hepatotoxic } \\
\text { Insecticidal }\end{array}$ & $\begin{array}{l}\text { O’Neill et al. (2010) } \\
\text { Bossou et al. (2013) } \\
\text { De Castro et al.(2016) }\end{array}$ \\
\hline 1,8-Diazabicyclo[5.4.0]undec-7-ene & Herbicidal & Cao et al. (2011) \\
\hline Pyrethroid & $\begin{array}{l}\text { Antifungal } \\
\text { Antimicrobial } \\
\text { Inseticidal }\end{array}$ & $\begin{array}{c}\text { Chattapadhyay and Dureja (2006) } \\
\text { Viegas Júnior (2003) }\end{array}$ \\
\hline
\end{tabular}


acid, alpha mannofuranoside, octadecenoic acid and spirosol-5-en-3-ol (solasodine). These activities have been reported in the literature. Walters et al. (2004) reported that 9-octadecenoic acid or oleic acid is an antifungal agent against Crinipellis pernicosa and Pythium ultimum. Ali et al. (2017) corroborate this result, presenting the fungal activity for this compound. It is also described as an antimicrobial and nematicide by Chandrasekaran et al. (2008). The compound milbemycin is reported to be an antiparasitic (Hugar and Londonkar, 2017) and Martín et al. (2017) attributed antiviral action to cytidine, which is a pyrimidine core compound that plays a vital role in biological activities such as antifungal. The compound solasodine is a highly toxic glycoalkaloid commonly found in the Solanaceae family, described by some authors (Al et al., 2016; Kausar and Singh, 2018; Patel et al., 2013; Yuan et al., 2017). Zeng et al. (2009) reported quinic acid anti-inflammatory activity.

In addition, as can be seen in Tables 3 and 4, other bioactive compounds were identified in $S$. viarum extracts (Table 5). The findings of chemical constituents corroborate that described by Kausar and Singh (2018) when studying the leaves of S. viarum, such as solasodine and quinic acid. Braguini et al. (2018) reported toxicity of $S$. viarum fruits against Artemia salina. High percentages of polyphenols and tannins were described, concluding that the fruits are highly toxic and may be a risk to livestock because they are available in the pastures.

\section{CONCLUSIONS}

In conclusion, this study showed that higher temperature and higher pressure presented higher extraction yields for SFE-CO ${ }_{2}$. However, this condition did not provide the highest percentage of the major compounds. When comparing this technique with Soxhlet, it showed higher yields. However, the superiority of SFE- $\mathrm{CO}_{2}$ in the composition is visible. For UAE, yields and chemical composition were higher than SFE- $\mathrm{CO}_{2}$, noting that higher values of intensity and pulse cycle favored the increase of yields. In general, it can be concluded that the UAE and SFE- $\mathrm{CO}_{2}$ techniques are efficient for extraction from $S$. viarum and the extracts obtained are a potential source of bioactive compounds, which must be further studied regarding the potential activities.

\section{ACKNOWLEDGEMENTS}

The authors thank the $\mathrm{CNPq}$ (National Council of Technological and Scientific Development, 428180/2018-3) and FAPERGS (Research Support Foundation of the State of Rio Grande do Sul) for the financial support of this work, as well as CAPES
(Coordination for the Improvement ofHigher Education Personnel, finance code 001) for scholarships. M. A. Mazutti, M. V. Tres (308936/2017-5) and G. L. Zabot (304882/2018-6) thank the CNPq for the productivity grants.

\section{REFERENCES}

Abu backer, M. N., Devi, P. K. In vitro antifungal potentials of bioactive compounds heptadecane, 9- hexyl and ethyl iso-allocholate isolated from Lepidagathis cristata Willd. (Acanthaceae) Leaf. British Biomedical Bulletin, 3, 336-343 (2015).

Agoramoorthy, G., Chandrasekaran, M., Venkatesalu, V., Hsu, M. J. Antibacterial and antifungal activities of fatty acid methyl esters of the blindyour-eye Mangrove from India. Brazilian Journal Microbiology, 38, 739-742 (2007).

Al, S. S., Eltayeb, E. A., Kamal, Y. T., Khan, M. S., Ahmad, S. Variations in the cytotoxic glycoalkaloids Solamargine and Solasonine in different parts of the Solanum incanum plant during its growth and development in oman. Integrative Medicine Research, 10, 813-822 (2016).

Aladić, K., Jarni, K., Barbir, T., Vidović, S., Vladić, J., Bilić, M., Jokić, S. Supercritical $\mathrm{CO}_{2}$ Extraction of Hemp (Cannabis sativa L.) Seed Oil. Industrial Crops Products, 76, 472-478 (2015).

Ali, A., Javaid, A., Shoaib, A. GC-MS analysis and antifungal activity of methanolic root extract of Chenopodium album against Sclerotium rolfsii. Planta Daninha, 35, 1-8 (2017).

Alvarez, M. V., Cabred, S., Ramirez, C. L., Fanovich, M. A. Valorization of an agroindustrial soybean residue by supercritical fluid extraction of phytochemical compounds. The The Journal of Supercritical Fluids, 143, 90-96 (2019).

Amanian, R. S., Brindha, P. In-vitro, antioxidant and GC-MS studies on Centratherum punctatum Cass. I. International Journal of Pharmacy and Pharmaceutical Sciences, 5, 3-6 (2013).

Aminah, A., Jusoff, K., Hadijah, S., Nuraeni, N, Reta, R., Marliana, S. P., Muchtar, A. H., Nonci, M. Increasing soybean (Glycine $\max \mathrm{L}$ ) drought resistance with osmolit sorbitol. Modern Applied Science, 7, 78-85 (2013).

Barretto, D., Vootla, S. Gc-Ms analysis of bioactive compounds and antimicrobial activity of Cryptococcus rajasthanensis Ky627764 Isolated From Bombyx mori gut microflora. Intermational Journal Advan Research, 6, 525-538 (2018).

Bernardo, C. O., Ascheri, J. L. R., Chávez, D. W. H., Carvalho, C. W. P. Ultrasound assisted extraction of yam (Dioscorea bulbifera) starch: effect on morphology and functional properties. Starch/ Staerke, 70, 1-10 (2018). 
Bossou, A. D., Mangelinckx, S., Yedomonhan, H., Boko, P. M., Akogbeto, M. C., Kimpe, N. De, Avlessi, F., Sohounhloue, D. C. K. Chemical composition and insecticidal activity of plant essential oils from benin against Anopheles gambiae (Giles). Parasites and Vectors, 6, 1-17 (2013).

Braguini, W. L., Pires, N. V., Alves, B. B. Phytochemical analysis, antioxidant properties and brine shrimp lethality of unripe fruits of Solanum viarum. Journal of Young Pharmacists, 10, 159-163 (2018).

Bubalo, M. C., Vidovi, S., Radoj, I. Green solvents for green technologies. Journal of Chemical Technology \& Biotechnology, 90, 1631-1639 (2015).

Cabaleero, A. S., Romero-García, J. M., Castro, E., Cardona, C. A. Supercritical Fluid Extraction for Enhancing Polyphenolic Compounds Production from Olive Waste Extracts. Journal of Chemical Technology \& Biotechnology, (2018).

Cao, G., Wang, M., Wang, M., Wang, S., Li, Y., Li, Z. Synthesis and herbicidal activity of novel sulfonylurea derivatives. Chemical Research in Chinese Universities, 27, 60-65 (2011).

Casuga, F. P., Castillo, A. L., Corpuz, M. J. A. T. GCMS Analysis of bioactive compounds present in different extracts of an endemic plant Broussonetia luzonica (Blanco) (Moraceae) leaves. Asian Pacific Journal of Tropical Biomedicine, 6, 957-961 (2016).

Chandrasekaran, M., Kannathasan, K., Venkatesalu, V. Antimicrobial activity of fatty acid methyl esters of some members of Chenopodiaceae. Zeitschrift fur Naturforsch. Journal of Biosciences, 63, 331-336 (2008).

Chattapadhyay, T. K., Dureja, P. Antifungal Activity of 4-Methyl-6-Alkyl-2H-Pyran-2-Ones. Journal of Agricultural and Food Chemical, 54, 2129-2133 (2006).

Chemat, F., Rombaut, N., Sicaire, A. G., Meullemiestre, A., Fabiano-Tixier, A. S., Abert-Vian, M. Ultrasound assisted extraction of food and natural products. mechanisms, techniques, combinations, protocols and applications. A Review. Ultrasonics Sonochemistry, 34, 540-560 (2017).

Chen, Q., Song, J., Bi, J., Meng, X., Wu, X. Characterization of volatile profile from ten different varieties of Chinese Jujubes by HS-SPME/ GC-MS Coupled with E-Nose. Food Research International, 105, 605-615 (2018).

Cipollini, M. L., Levey, D. J. Why Are Some Fruits Toxic? Glycoalkaloids in solanumand fruit choice by vertebrates. Ecology, 78, $782-798$ (1997).

Confortin, T. C., Todero, I., Ferreira, J. S., Brun, T., Luft, L., Ugalde, G. A., Prá, V. D., Mazutti,
M. A., Zabot, G. L., Tres, M. V. Extraction and composition of extracts obtained from Lupinus albescens using supercritical carbon dioxide and compressed liquefied petroleum gas. The Journal of Supercritical Fluids, 128, 395-403 (2017).

Confortin, T. C., Todero, I., Luft, L., Ugalde, G. A., Mazutti, M. A., Oliveira, Z. B., Bottega, E. L., Knies, A. E., Zabot, G. L., Tres, M. V. Oil Yields, protein contents, and cost of manufacturing of oil obtained from different hybrids and sowing dates of Canola. Journal of Environmental Chemical Engineering, 7, 102972 (2019).

Corbin, C., Fidel, T., Leclerc, E. A., Barakzoy, E., Sagot, N., Falguiéres, A., Renouard, S., Blondeau, J. P., Ferroud, C., Doussot, J., Lainé, E., Hano, C. Development and validation of an efficient ultrasound assisted extraction of phenolic compounds from flax (Linum usitatissimum L.) seeds. Ultrasonics Sonochemistry, 26, 176-185 (2015).

Dal Prá, V., Dolwitsch, C. B., Lima, F. O., Carvalho, C. A., Viana, C. N. P. C., Rosa, M. B. UltrasoundAssisted Extraction and Biological Activities of Extracts of Brassica oleracea var. capitata. Food Technology and Biotechnology, 53, 102-109 (2015).

Dal Prá, V., Soares, J. F., Monego, D. L., Vendruscolo, R. G., Freire, D. M. G., Alexandri, M., Koutinas, A., Wagner, R., Mazutti, M. A., Da Rosa, M. B. Extraction of bioactive compounds from palm (Elaeis guineensis) pressed fiber using different compressed fluids. The Journal of Supercritical Fluids, 112, 51-56 (2016).

Castro, D. S. B., Silva, D. B. da, Tibúrcio, J. D., Sobral, M. E. G., Ferraz, V., Taranto, A. G., Serrão, J. E., Siqueira, J. M. de, Alves, S. N. Larvicidal activity of essential oil of Peumus boldus Molina and Its Ascaridole-Enriched Fraction against Culex quinquefasciatus. Experimental Parasitology, 171, 84-90 (2016).

De Melo, M. M. R., Silvestre, A. J. D., Silva, C. M. Supercritical fluid extraction of vegetable matrices: applications, trends and future perspectives of a convincing green technology. The Journal of Supercritical Fluids, 92, 115-176 (2014).

Demuner, A. J., Longue Filho, M., Barbosa, L. C., Santos, M. A. Síntese e avaliação da atividade nematicida de derivados da piperazina. Eclética Química, 26 (2001).

Easmin, M. S., Sarker, I., Ferdosh, S., Shamsudin, H., Yunus, B., Uddin, S., Sarker, M. R., Akanda, H., Abdul, H. P. S. Bioactive compounds and advanced processing technology: Phaleria macrocarpa (Sheff) Boerl, a Review. Journal of Chemical Technology \& Biotechnology, 90, 981991 (2015). 
Elgndi, M. A., Filip, S., Pavlić, B., Vladić, J., Stanojković, T., Žižak, Ž., Zeković, Z. Antioxidative and cytotoxic activity of essential oils and extracts of Satureja montana L., Coriandrum sativum L. and Ocimum basilicum L. Obtained by supercritical fluid extraction. The Journal of Supercritical Fluids, 128, 128-137 (2017).

Entigu, R., Lihan, S., bin Ahmad, I. The Effect of combination of octadecanoic acid, methyl ester and ribavirin against Measles virus. International Journal of Scientific \& Technology Research, 2, 181-184 (2013).

Farías-Campomanes, A. M., Rostagno, M. A., Meireles, M. A. A. Production of polyphenol extracts from Grape bagasse using supercritical fluids: yield, extract composition and economic evaluation. The Journal of Supercritical Fluids, 77, 70-78 (2013).

Foo, L. W., Salleh, E., Nur, S., Mamat, H. P-53:Extraction and qualitative analysis of Piper betle leaves for antimicrobial activities. International Journal of Engineering Technology Science and Research, 2, 1-8 (2015).

Fraga, B. M., González-Coloma, A., Alegre-Gómez, S., López-Rodríguez, M., Amador, L. J., Díaz, C. E. Bioactive constituents from transformed root cultures of Nepeta teydea. Phytochemistry, 133, 59-68 (2017).

Gadkari, P. V., Balaraman, M. Mass trasnfer andkinetic modelling of supercritical $\mathrm{CO}_{2}$ extraction of fresh tea leaves (Camellia sinensis L.). Brazilian Journal of Chemical Engineering, 34, 799-810 (2017).

Goltz, C., Ávila, S., Barbieri, J. B., Igarashi-Mafra, L., Mafra, M. R. Ultrasound-assisted extraction of phenolic compounds from Macela (Achyrolcine satureioides) extracts. Industrial Crops and Products, 115, 227-234 (2018).

Govindappa, M., Prathap, S., Vinay, V., Channabasava, R. Chemical composition of methanol extract of endophytic fungi, Alternaria sp. of Tebebuia argentea and their antimicrobial and antioxidant activity. International Journal of Biological \& Pharmaceutical Research, 5, 861-869 (2014).

Goyeneche, R., Fanovich, A., Rodriguez Rodrigues, C., Nicolao, M. C., Di Scala, K. Supercritical $\mathrm{CO}_{2}$ extraction of bioactive compounds from radish leaves: yield, antioxidant capacity and cytotoxicity. The Journal of Supercritical Fluids, 135, 78-83 (2018).

Martín, S., Grande-pérez, A., Cuevas, J. M., Elena, S. F. Putative antiviral role of plant cytidine deaminases [ Version 2, Referees : 2 Approved ] Referee Status 0, 1-14 (2017).

Günthardt, B. F., Hollender, J., Hungerbühler, K., Scheringer, M., Bucheli, T. D. Comprehensive toxic plants-phytotoxins database and its application in assessing aquatic micropollution potential. Journal of Agricultural and Food Chemistry, 66, 7577-7588 (2018).

Hsouna, A. Ben, Trigui, M., Mansour, R. Ben, Jarraya, R. M., Damak, M., Jaoua, S. Chemical composition, cytotoxicity effect and antimicrobial activity of Ceratonia siliqua essential oil with preservative effects against Listeria inoculated in minced beef meat. International Journal of Food Microbiology, 148, 66-72 (2011).

Hugar, A. L., Londonkar, R. L. GC-MS Profiling of bioactive components from aqueous extract of pterocarpus Marsupium. International Journal of ChemTech Research, 10, 557-564 (2017).

Jalili, F., Jafari, S. M., Emam-Djomeh, Z., Malekjani, N., Farzaneh, V. Optimization of ultrasoundassisted extraction of oil from Canola seeds with the use of response surface methodology. Food Analytical Methods, 11, 598-612 (2018).

Kadam, S. U., Tiwari, B. K., O’Donnell, C. P.Application of novel extraction technologies for bioactives from Marine algae. Journal of Agricultural and Food Chemistry, 61, 4667-4675 (2013).

Kausar, M., Singh, B. K. Pharmacological evaluation of Solanum viarum Dunal leaves extract for analgesic and antipyretic activities. Journal of Drug Delivery and Therapeutics, 8, 356-361 (2018).

Kiss, A. A., Geertman, R., Wierschem, M., Skiborowski, M., Gielen, B., Jordens, J., John, J., Gerven, T. Van. Ultrasound-assisted emerging technologies for chemical processes. Journal of Chemical Technology \& Biotechnology, 93, 12191227 (2018).

Krishnan, K., Mani, A., Jasmine, S. Cytotoxic activity of bioactive compound 1, 2- Benzene Dicarboxylic Acid, Mono 2- Ethylhexyl Ester extracted from a marine derived Streptomyces sp. VITSJK8. International Journal of Molecular and Cellular Medicine, 3, 246-254 (2014).

Kulkarni, V. M., Rathod, V. K. Mapping of an ultrasonic bath for ultrasound assisted extraction of Mangiferin from Mangifera indica Leaves. Ultrasonics Sonochemistry, 21, 606-611(2014).

Lichtfouse, E. Sustainable Agriculture Reviews, Vol. 12. (2013)

Marques, C., Tarek, R., Sara, M., Brar, S. K. Sorbitol Production From Biomass and Its Global Market. In Kaur Brar, S., Jyoti Sarma, S., Pakshirajan, K. (eds.) Platform Chemical Biorefinery, 217-227 (2016).

Martinez-Correa, H. A., Bitencourt, R. G., Kayano, A. C. A. V., Magalhães, P. M., Costa, F. T. M., Cabral, F. A. Integrated extraction process to obtain bioactive extracts of Artemisia annua L. leaves using supercritical $\mathrm{CO}_{2}$, ethanol and water. Industrial Crops and Products, 95, 535-542 (2017). 
Mentz, L. A., Lutzemberger, L., Schenkel, E. P. Da flora medicinal do Rio Grande do Sul: notas sobre a obra de D'ávila (1910). Caderno de Farmácia, 5, 25-48 (1997).

Milner, S. E., Brunton, N. P., Jones, P. W., O Brien, N. M., Collins, S. G., Maguire, A. R. Bioactivities of glycoalkaloids and their aglycones from Solanum species. Journal of Agricultural and Food Chemistry, 59, 3454-3484 (2011).

Miranda, A. L. de, Ribeiro, M. C., Felipe, R., Moreira, A., Alberto, C., Maria, B. de. Volatile profile of heated soybean oil treated with quercetin and chlorogenic acid. Food Science anda Tecnology, 8, 949-952 (2008).

Mohammadpour, H., Sadrameli, S. M., Eslami, F., Asoodeh, A. Optimization of ultrasound-assisted extraction of Moringa peregrina oil with response surface methodology and comparison with soxhlet method. Industrial Crops and Products, 131, 106116 (2019).

Moraes, M. N., Zabot, G. L., Meireles, M. A. A. Extraction of tocotrienols from annatto seeds by a pseudo continuously operated SFE process integrated with low-pressure solvent extraction for bixin production. The Journal of Supercrit Fluids, 96, 262-271 (2015).

Muthulakshmi, A. R. J. M., Mohan, V. R. GC-MS Analysis of bioactive components of Feronia elephantum Correa (Rutaceae). Journal of Applied Pharmaceutical Science, 2, 69-74 (2012).

O'Neill, P. M., Barton, V. E., Ward, S. A. The molecular mechanism of action of artemisinin - the debate continues. Molecules, 15, 1705-1721 (2010).

Patel, K., Singh, R. B., Patel, D. K. Medicinal Significance, Pharmacological Activities, and Analytical Aspects of Solasodine: A Concise Report of Current Scientific Literature. Journal of Acute Disease, 2, 92-98 (2013).

Patil, D. M., Akamanchi, K. G. Ultrasound-assisted rapid extraction and kinetic modelling of influential factors: extraction of camptothecin from Nothapodytes nimmoniana Plant. Ultrasonics Sonochemistry, 37, 582-591 (2017).

Pauli, A. $\alpha$-Bisabolol from Chamomile - A Specific ergosterol biosynthesis inhibitor? International Journal of Medicinal and Aromatic Plants, 13, 2125 (2006).

Petigny, L., Périno-issartier, S., Wajsman, J., Chemat, F. Batch and continuous ultrasound assisted extraction of Boldo leaves ( Peumus boldus Mol.). International Journal of Molecular Sciences, 14, 5750-5764 (2013).

Picó, Y. Ultrasound-assisted extraction for food and environmental samples. TrAC - Trends in Analytical Chemistry, 43, 84-99 (2013)
Piochon, M., Legault, J., Gauthier, C., Pichette, A. Phytochemistry synthesis and cytotoxicity evaluation of natural a-Bisabolol b-DFucopyranoside and Analogues. Phytochemistry, 70, 228-236 (2009).

Prado, J. M., Dalmolin, I., Carareto, N. D. D., Basso, R. C., Meirelles, A. J. A., Oliveira, J. V., Batista, E. A. C., Meireles, M. A. A. Supercritical fluid extraction of grape seed: process scale-up, extract chemical composition and economic evaluation. Journal of Food Engineering, 109, 249-257 (2012).

Prakash Maran, J., Manikandan, S., Vigna Nivetha, C., Dinesh, R. Ultrasound assisted extraction of bioactive compounds from Nephelium lappaceum L. fruit peel using central composite face centered response surface design. Arabian Journal of Chemistry, 10, 1145-1157 (2017).

Rouhani, M. Modeling and Optimization of Ultrasoundassisted green extraction and rapid hptlc analysis of stevioside from Stevia rebaudiana. Industrial Crops and Products, 132, 226-235 (2019).

Sallet, D., Souza, P. O., Fischer, L. T., Ugalde, G., Zabot, G. L., Mazutti, M. A., Kuhn, R. C. Ultrasound-assisted extraction of lipids from Mortierella isabellina. Journal of Food Engineering, 242, 1-7 (2019).

Sanseera, D., Niwatananun, W., Liawruangrath, B., Liawruangrath, S., Baramee, A., Pyne, S. G. Chemical composition and biological activities of the essential oil from leaves of Cleidion javanicum. Journal of Essenstial Oil Bearing Plants, 15, 186194 (2013).

Santos-Zea, L., Gutiérrez-Uribe, J. A., Benedito, J. Effect of ultrasound intensification on the supercritical fluid extraction of phytochemicals from Agave salmiana bagasse. The Journal of Supercritical Fluids, 144, 98-107 (2019).

Santos, K. A., Gonçalves, J. E., Cardozo-Filho, L., Silva, E. A. da. Pressurized liquid and ultrasoundassisted extraction of $\alpha$-Bisabolol from Candeia (Eremanthus erythropappus) Wood. Industrial Crops and Products, 130, 428-435 (2019).

Selvamangai, C., Bhaskar, A. GC-MS Analysis of Phytocomponents in the Methanolic Extract of Eupatorium triplinerve. International Journal of Drug Development and Research, 4, 148-153 (2012).

Soares, J. F., Dal Prá, V., Souza, M. de, Lunelli, F. C., Abaide, E., Silva, J. R. F. da, Kuhn, R. C., Martínez, J., Mazutti, M. A. Extraction of rice bran oil using supercritical $\mathrm{CO}_{2}$ and compressed liquefied petroleum gas. Journal of Food Engineering, 170, 58-63 (2016).

Soares, J. F., Dal Prá, V., Barrales, F. M., Santos, P., Kuhn, R. C., Rezende, C. A., Martínez, J., Mazutti, M. A. Extraction of rice bran oil using supercritical $\mathrm{CO}_{2}$ combined with ultrasound. Brazilian Journal of Chemical Engineering, 35, 785-794 (2018). 
Valente, I. de L., Confortin, T. C., Luft, L., Ugalde, G. A., Zabot, G. L., Mazutti, M. A., Terra, L. de M. Extraction of bioactive compounds from Botryosphaeria dothidea using supercritical carbon dioxide and compressed liquefied petroleum gas. The Journal of Supercritical Fluids, 136, 52-59 (2018).

Verma, A., Johri, B. N., Prakash, A. Antagonistic Evaluation of Bioactive Metabolite from Endophytic Fungus, Aspergillus Flavipes KF671231. Journal of Mycology, 2014, 1-5 (2014).

Viegas, C. Terpenos com atividade inseticida: uma alternativa para o controle químico de insetos. Química Nova, 26, 390-400 (2003).

Vinatoru, M., Mason, T. J., Calinescu, I. Ultrasonically assisted extraction (UAE) and microwave assisted extraction (MAE) of functional compounds from plant materials. TrAC - Trends in Analytical Chemistry, 97, 159-178 (2017).

Vuong, Q. V., Nguyen, V. T., Thanh, D. T., Bhuyan, D. J., Goldsmith, C. D., Sadeqzadeh, E., Scarlett, C. J., Bowyer, M. C. Optimization of ultrasound-assisted extraction conditions for euphol from the medicinal plant, euphorbia tirucalli, using response surface methodology. Industrial Crops and Products, 63, 197-202 (2015).

Walters, D., Raynor, L., Mitchell, A., Walker, R., Walker, K. Antifungal activities of four fatty acids against plant pathogenic fungi. Mycopathologia, 157, 87-90 (2004).

Wei, Y. qin, Sun, M. man, Fang, H. yan. Dienzymeassisted salting-out extraction of flavonoids from the seeds of Cuscuta chinensis Lam. Industrial Crops and Products, 127, 232-236 (2019).
Yuan, B., Byrnes, D., Giurleo, D., Villani, T., Simon, J. E., Wu, Q. Rapid screening of toxic glycoalkaloids and micronutrients in edible nightshades ( Solanum spp.). Journal of Food and Drug Analysis, 26, 751760 (2017).

Zabot, G. L., Moraes, M. N., Carvalho, P. I. N., Meireles, M. A. A. New proposal for extracting rosemary compounds: process intensification and economic evaluation. Industrial Crops and Products, 77, 758-771 (2015).

Zabot, G. L., Moraes, M. N., Meireles, M. A. A. Process integration for producing tocotrienols-rich oil and bixin-rich extract from Annatto seeds: a techno-economic approach. Food and Bioproducts Processing, 109, 122-138 (2018).

Zabot, G. L., Silva, E. K., Azevedo, V. M., Meireles, M. A. A. Replacing modified starch by inulin as prebiotic encapsulant matrix of lipophilic bioactive compounds. Food Research International, 85, 26-35 (2016).

Zeng, K., Thompson, K. E., Yates, C. R., Miller, D. D. Synthesis and biological evaluation of quinic acid derivatives as anti-inflammatory agents. Bioorganic \& Medicinal Chemistry Letters, 19, 5458-5460 (2009).

Zhong, J., Wang, Y., Yang, R., Liu, X., Yang, Q., Qin, $\mathrm{X}$. The application of ultrasound and microwave to increase oil extraction from Moringa oleifera seeds. Industrial Crops and Products, 120, 1-10 (2018).

Zhou, P., Wang, X., Liu, P., Huang, J., Wang, C., Pan, M., Kuang, Z. Enhanced phenolic compounds extraction from Morus alba L. leaves by deep eutectic solvents combined with ultrasonic-assisted extraction. Industrial Crops and Products, 120, 147-154 (2018). 